\title{
Ultrasonic Testing of HPC with Mineral Admixtures
}

\author{
R. Hamid, K. M. Yusof and M. F. M. Zain \\ Universiti Kebangsaan Malaysia \\ Malaysia
}

\section{Introduction}

High strength and high performance concrete (HSC and HPC) have been introduced commercially for the columns of high-rise buildings in 1970s in the United States of America and now being made worldwide, one example being the tallest building in Malaysia, the Petronas Twin Towers (Shah, 1997). Fly ash, silica fume, or slag are often mandatory in the production of high-strength and high performance concrete for the reason that the strength gain obtained with these supplementary cementing materials cannot be attained by using additional cement alone. These mineral additives are usually added at dosage rates of $5 \%$ to $20 \%$ or higher by mass of cementing material (Portland Cement Association EB001 [PCA EB001], 2002). HSC and HPC with mineral additives have different microstructure than normal concrete. The matrix is denser and has lower capillary porosity compared to ordinary concrete. In HSC at more than $105 \mathrm{MPa}$ with silica fume, the matrix is perfectly homogenous, apparently amorphous and the capillary porosity is diminished and discontinuous compared to that of other concretes where it is interconnected (Malier, 1992).

There are a number of ultrasonic testing techniques applied to concrete since 40 years ago (International Atomic Energy Agency TCS 17 [IAEA TCS17], 2002). These techniques are relatively not as sophisticated as compared to other materials application such as metals, but it is found that these techniques are relevant in some cases. These techniques include ultrasonic pulse velocity (UPV), ultrasound pulse echo, the amplitude or the pulse energy measurement, impact-echo/resonance frequency/stress wave test (pulse-echo, impact-echo, impulseresponse and spectral analysis of surface waves), and relative amplitude method (RA).

Ultrasonic pulse velocity measurement in concrete is applicable in assessing the quality of concrete. The UPV measurements are correlated with the concrete strength as a measure of concrete quality. For normal concrete with ordinary Portland cement, with strength range between $5 \mathrm{MPa}$ up to $60 \mathrm{MPa}$, the empirical correlations between strength and UPV are recorded as in the form of exponential (Bungey, 1984; Facaoaru, 1969; Popovics, 1986; Teodaru, 1989; etc as cited in Ismail et al., 1996) with correlation equation, $\mathrm{R}^{2}$ higher than $90 \%$. For strength between $5 \mathrm{MPa}$ to $60 \mathrm{MPa}$, the UPV varies between as low as below 2.0 $\mathrm{km} / \mathrm{s}$ and as high as more than $4.7 \mathrm{~km} / \mathrm{s}$. The exponential relationship between the UPV and strength is expressed as: 


$$
K=a e^{b v}
$$

where $K$ is the compressive strength of concrete, $v$ is the UPV and $a$ and $b$ are the empirical constants.

Researches on improvement on the strength-UPV correlation are done vastly either to have more accurate relationship (there are many factors that affect the UPV measured but not the concrete strength) or to make it applicable in assessing concrete structures (Carino, 1994). British Standard (BS 1881: Part 203. Testing Concrete - Recommendation for measurement of velocity of ultrasonic pulses in concrete) listed some factors that affect the ultrasonic pulse measurement in concrete. These factors are path length; lateral dimension of the specimen tested; moisture content of the concrete; temperature of the concrete and the presence of reinforcing steel. The corrections for each factor are as suggested by BS 1881: Part 203.

As the usage of mineral admixtures is inevitable in HPC, researches on influence of additional cementitious materials on strength as well as UPV have been studied. Demirbogă et al., 2004; Türkmen et al., 2010 reported the coefficient of correlation $\left(\mathrm{R}^{2}\right)$ of more than 0.90 which indicate a very good exponential relationship between UPV and compressive strength of concrete containing Portland cement, fly ash (FA), natural zeolite (NZ) and blast furnace slag (BFS) and both NZ + BFS concrete (Figure 1). They confirmed the exponential relationship of strength-UPV of concrete with these mineral admixtures (as expressed in Eq. 1). The UPV measured varies between $3250 \mathrm{~m} / \mathrm{s}$ at strength of $5 \mathrm{MPa}$ up to $4400 \mathrm{~m} / \mathrm{s}$ at strength $55 \mathrm{MPa}$. As the concrete strength increase, as in HPC and HSC, the exponential relationship still applied (Khatib, 2008; Hamid et al., 2010), but for strength range between 60 to $100 \mathrm{MPa}$, the variation of UPV is between 4.5 to $5.0 \mathrm{~km} / \mathrm{s}$, making the UPV measurement insensitive towards the variation of strength of HPC and HSC in which their strengths are in this range (Figure 2).

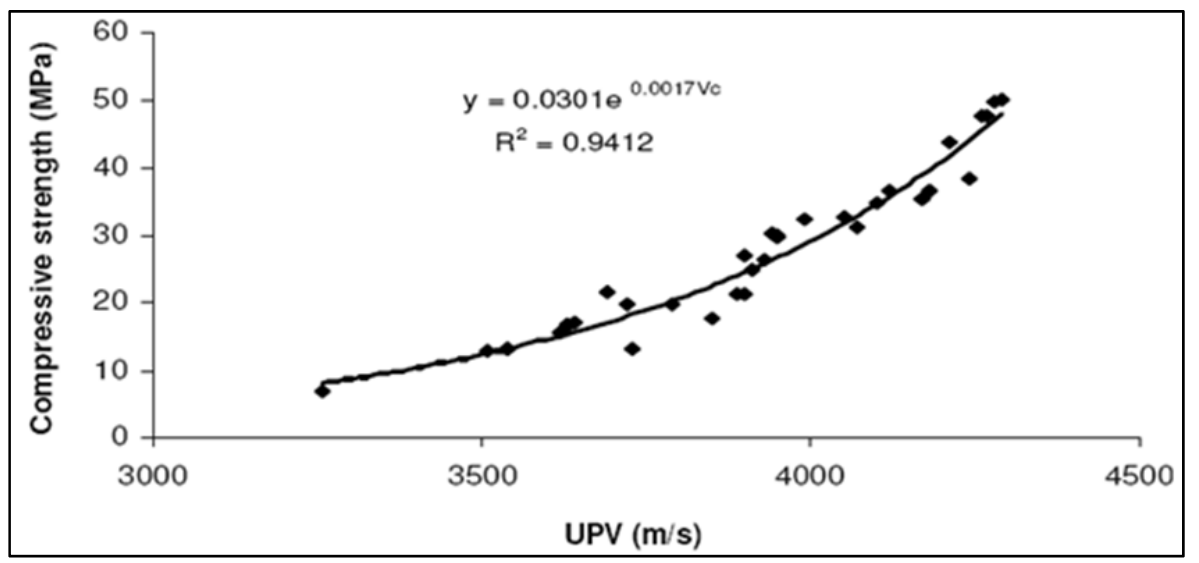

Fig. 1. Relationship between compressive strength and UPV for all results between 3 and 90 days of curing periods for Portland cement, natural zeolite (NZ) and blast furnace slag (BFS) and both NZ + BFS concrete (Türkmen et al., 2010)

Relative amplitude (RA) method is an alternative method to assess the concrete strength (IAEA TCS17, 2002). The principle of this method will be discussed further in this chapter. 
Ismail et al., 1996 described the relationship between RA and strength for normal concrete up to $60 \mathrm{MPa}$. The RA-strength relationship of HPC with silica fume is also described (Hamid et al., 2010). Meanwhile, researches on combined ultrasound method were done to have more accurate estimation of concrete strength (Galan, 1990). The strength of normal concrete has been successfully estimated with only 5\% error using the combination of ultrasonic pulse velocity-strength and relative amplitude-strength correlation curves (Ismail et al., 1996).

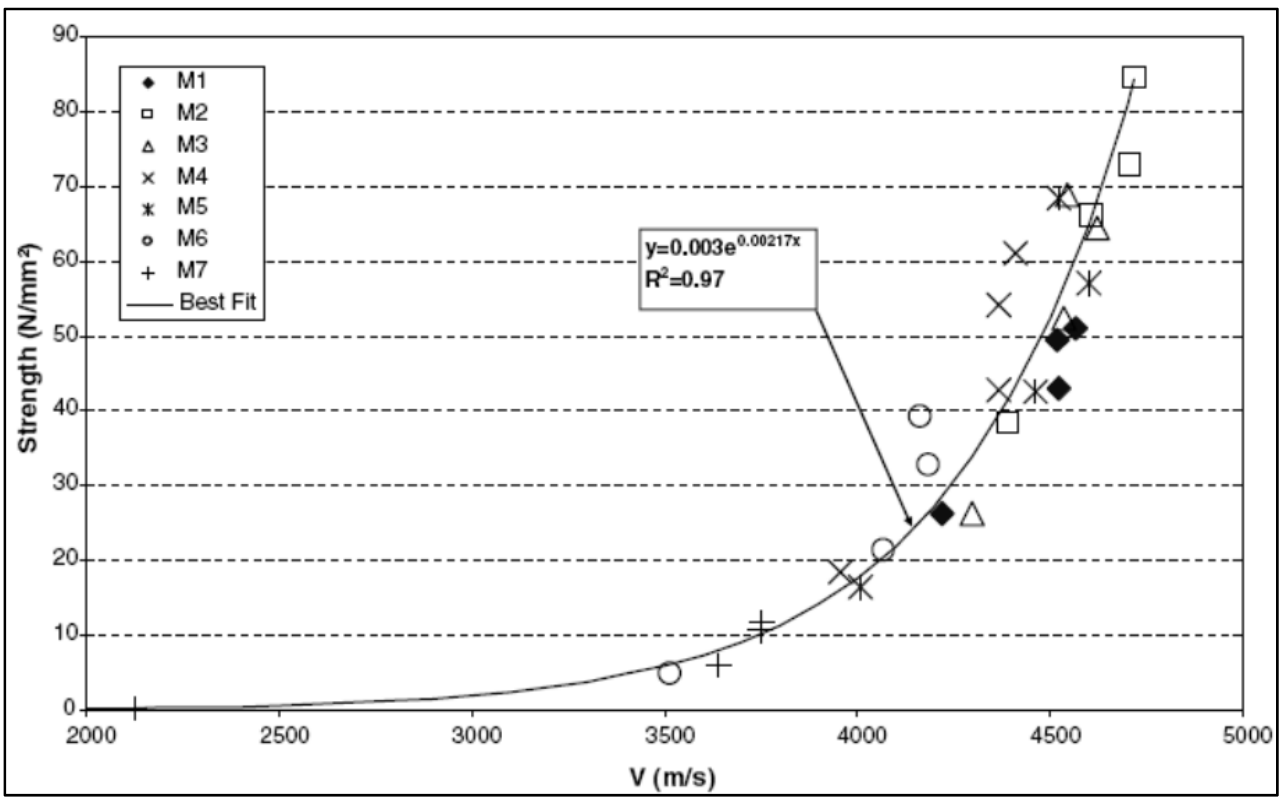

Legend: M1, M2, M3 - 0\% FA; M4 - 20\% FA; M5 - 40\% FA; MA6 - 60\%FA; MA7 - 80\%FA

Fig. 2. Relationship between strength and UPV for concrete with different proportion of fly ash (FA) (Khatib, 2008)

This chapter emphasizes on ultrasonic pulse velocity (UPV) method in assessing the strength of high performance concrete (HPC) with mineral admixtures particularly fly ash and silica fume. Adding mineral admixtures to replace certain percentages of cement content increase the strength of HPC compare to the same concrete combination containing only ordinary Portland cement (OPC). This chapter discusses further in detail results of experiments on the UPV and RA method in strength estimation of HPC with fly ash.

\section{Experimental program, results and discussion}

\subsection{Experimental program}

About 300 specimens, representing 32 trial mixes were prepared and tested in this study. Fabrication, curing and testing of specimens were done based on ASTM C 192, ASTM C618, ACI Committee 211, BS 1881: Part 116 and BS 1881: Part 203. 


\subsubsection{Materials}

The cement used is Type I Portland cement produced locally and conforms with the Malaysian Standard. Its specific gravity is 3.15 (SI unit) and the moisture content is $0.6 \%$. The finess modulus of the mine sand used is 2.48 , with its maximum size at $4.75 \mathrm{~mm}$; specific gravity 2.25 (SI unit) and total moisture content $2.1 \%$. The maximum size of granite aggregate used is $20 \mathrm{~mm}$, its specific gravity is 2.29 (SI unit) and the total moisture content is at $0.7 \%$. Superplasticizer (SP) used in this study is a naphthalene formaldehyde sulfate based condensed superplasticizer with brand name Super-20 supplied by Ready Mixed Concrete Malaysia. Its specific gravity is 1.21 (SI unit) with $40 \%$ of solid content and $0 \%$ chloride content.

\subsubsection{Mix design}

To reduce the number of variants, the ratio of sand to aggregate is held constant at 0.4 . Any admixtures added in the form of liquid, is calculated as part of the mixing water. Three series of HPC were designed with 10, 20 and 30\% replacement with class F Malaysian fly ash plus one series of mixes with $0 \%$ fly ash content. Each series consisted of 10 different water/binder ratios ( 7 for mixes with $30 \% \mathrm{FA}$ and 5 for mixes with $0 \% \mathrm{FA}$ ) to get variation of strength, with the percentage of SP added were changed for each $w / b$ ratio in consideration for workability, but maintained within the series. The $\mathrm{w} / \mathrm{b}$ ratios are from 0.200 to 0.380 with 0.02 intervals or otherwise stated. Total cementitious materials are 600 $\mathrm{kg} / \mathrm{m}^{3}$ and the ratio of fine aggregate to coarse is 0.4 . Table 1 shows the detailed mixes in this study.

\subsubsection{Fabrication, curing and testing}

Mixing is done in a rotating mixer and enough time is allowed until the mix shows consistency visually. The actual time to achieve the mix consistency depends on the slump/workability of the mixes. Slump test is done on each water/binder ratio mix in each series. The test specimens are $150 \mathrm{~mm} \times 150 \mathrm{~mm} \times 150 \mathrm{~mm}$ cubes. The specimens are demoulded after 24 hours. One third of the total samples are immersed in water for 28 days, the other one third are immersed in water for 7 days and the last one third is let dried in open air inside an uncontrolled temperature and humidity building. The temperature inside the building is on average $32^{\circ} \mathrm{C}$. Compression test are done with a compression machine with the capacity of $3000 \mathrm{kN}$ after the ultrasonic testing were done. All tests are done on day 91 after casting with 3 samples tested for each test. The concrete specimens were tested in wet condition (more than 48 hours immersed in water before testing) as required by ASTM C 39.

\subsubsection{Method of ultrasonic testing}

Ultrasonic pulse velocity (UPV) is measured in materials by the equation:

$$
v=\frac{L}{T} \mathrm{~m} / \mathrm{s}
$$

where $v$ is the longitudinal (pressure) pulse velocity, $L$ is the path length and $T$ is the time taken by the pulse to traverse that length. 
A set up of the ultrasonic pulse velocity measurement on laboratory specimen is as shown in Figure 3.

\begin{tabular}{|c|c|c|c|c|c|c|}
\hline \multirow[t]{2}{*}{ Mix } & \multirow{2}{*}{$\begin{array}{c}\text { Water/ binder } \\
\text { ratio }\end{array}$} & \multicolumn{2}{|c|}{ Binder $\left(\mathrm{kg} / \mathrm{m}^{3}\right)$} & \multirow[t]{2}{*}{ SP (Liter) } & \multirow{2}{*}{$\begin{array}{c}\text { Sand } \\
\left(\mathrm{kg} / \mathrm{m}^{3}\right)\end{array}$} & \multirow{2}{*}{$\begin{array}{c}\text { Aggregate } \\
\left(\mathbf{k g} / \mathbf{m}^{3}\right)\end{array}$} \\
\hline & & Cement & Fly ash & & & \\
\hline I & $\begin{array}{l}0.220 \\
0.260 \\
0.300 \\
0.340 \\
0.380\end{array}$ & $\begin{array}{l}600 \\
600 \\
600 \\
600 \\
600\end{array}$ & $\begin{array}{l}0 \\
0 \\
0 \\
0 \\
0\end{array}$ & $\begin{array}{c}17.4 \\
14.9 \\
12.4 \\
9.9 \\
7.4\end{array}$ & $\begin{array}{l}653 \\
630 \\
607 \\
584 \\
561\end{array}$ & $\begin{array}{l}980 \\
945 \\
910 \\
876 \\
841\end{array}$ \\
\hline II & $\begin{array}{l}0.198 \\
0.216 \\
0.234 \\
0.252 \\
0.270 \\
0.288 \\
0.306 \\
0.324 \\
0.342 \\
0.360\end{array}$ & $\begin{array}{l}540 \\
540 \\
540 \\
540 \\
540 \\
540 \\
540 \\
540 \\
540 \\
540\end{array}$ & $\begin{array}{l}60 \\
60 \\
60 \\
60 \\
60 \\
60 \\
60 \\
60 \\
60 \\
60\end{array}$ & $\begin{array}{c}17.4 \\
17.4 \\
14.9 \\
14.9 \\
12.4 \\
9.9 \\
9.9 \\
7.4 \\
7.4 \\
7.4\end{array}$ & $\begin{array}{l}648 \\
638 \\
628 \\
618 \\
607 \\
597 \\
587 \\
576 \\
566 \\
556\end{array}$ & $\begin{array}{l}973 \\
957 \\
942 \\
926 \\
911 \\
895 \\
880 \\
865 \\
849 \\
834\end{array}$ \\
\hline III & $\begin{array}{l}0.200 \\
0.220 \\
0.240 \\
0.260 \\
0.280 \\
0.300 \\
0.320 \\
0.340 \\
0.360 \\
0.380\end{array}$ & $\begin{array}{l}480 \\
480 \\
480 \\
480 \\
480 \\
480 \\
480 \\
480 \\
480 \\
480\end{array}$ & $\begin{array}{l}120 \\
120 \\
120 \\
120 \\
120 \\
120 \\
120 \\
120 \\
120 \\
120\end{array}$ & $\begin{array}{c}19.8 \\
17.4 \\
17.4 \\
14.9 \\
14.9 \\
12.4 \\
9.9 \\
9.9 \\
7.4 \\
7.4\end{array}$ & $\begin{array}{l}643 \\
632 \\
620 \\
609 \\
597 \\
586 \\
575 \\
563 \\
552 \\
540\end{array}$ & $\begin{array}{l}965 \\
948 \\
930 \\
913 \\
896 \\
879 \\
862 \\
845 \\
828 \\
810\end{array}$ \\
\hline IV & $\begin{array}{l}0.260 \\
0.280 \\
0.300 \\
0.320 \\
0.340 \\
0.360 \\
0.380\end{array}$ & $\begin{array}{l}420 \\
420 \\
420 \\
420 \\
420 \\
420 \\
420\end{array}$ & $\begin{array}{l}180 \\
180 \\
180 \\
180 \\
180 \\
180 \\
180\end{array}$ & $\begin{array}{c}14.9 \\
14.9 \\
12.4 \\
9.9 \\
9.9 \\
7.4 \\
7.4\end{array}$ & $\begin{array}{l}602 \\
590 \\
579 \\
567 \\
556 \\
545 \\
533\end{array}$ & $\begin{array}{l}903 \\
885 \\
868 \\
851 \\
834 \\
817 \\
800\end{array}$ \\
\hline
\end{tabular}

Table 1. Details of Mix Proportions 


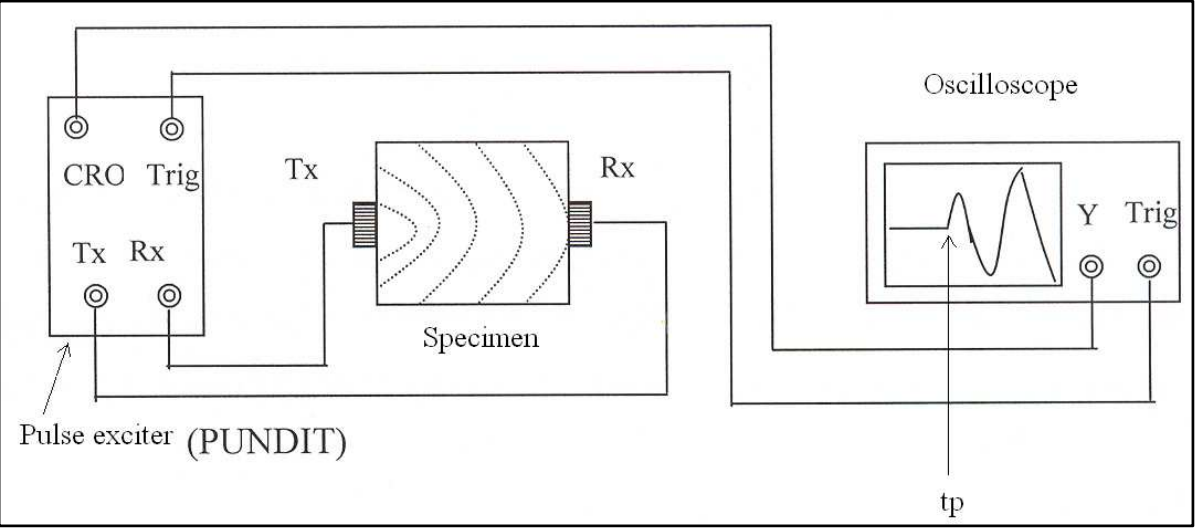

Tx - Transmitter

$\mathrm{Rx}$ - Receiver

CRO - Cathode Ray Oscilloscope

Trig - Trigger

Fig. 3. Ultrasonic pulse velocity measurement set up

The piezoelectric transducers (lead zirconate-lead titanates ceramic type) with frequencies of $54 \mathrm{kHz}, 82 \mathrm{kHz}$ and $180 \mathrm{kHz}$ as the ultrasonic pulse transmitter and receiver are employed. The ultrasonic pulse is generated by alternate current using commercial ultrasonic-scope (brand name PUNDIT) with digital display of transit time in microsecond. Figure 1 shows a digital storage oscilloscope connected to the pulse exciter to trace the transmitted wave from where the pulse amplitude is obtained. The oscilloscope display shows that the pulse amplitude is represented as displacement in one axis (normally y-axis) and the ultrasonic pulse transit time is represented by the displacement at the other axis (x-axis). The arrival time of the pressure wave (transit time) can be located as $t_{p}$ shown in Figure 3 . In linear amplification system, vertical displacement is proportional to the signal amplitude. By using logarithmic scale amplification, $\mathrm{y}$-axis is represented by logarithmic scale.

The relative amplitude method is basically an attenuation method, which measures the ratio of the wave amplitudes. Ultrasonic waves are attenuated as they pass through the materials. The attenuation of the sound pressure propagating in solid consists of two components, namely the geometric divergence and energy dissipation. For quality evaluation of materials, the dissipation factor is critical since it is related to the properties of the material. The dissipation effect consists of two processes, namely scattering and absorption. Scattering is due mainly to the non-homogenous composition of the medium and absorption is the actual loss of sound energy. When the properties of material vary, the intensity of the lost energy will also vary, thus the attenuation characteristic can be used to determine the properties of the material. For low amplitude sinusoidal wave, the attenuation of wave due to both conversion processes is in an exponent form and the incident amplitude (either the particle displacement amplitude or the pressure amplitude) can be expressed as [Krautkramer \& Krautkramer, 1983] :

$$
P_{a}=P_{0} e^{-\alpha x}
$$


where $\mathrm{P}_{0}$ and $\mathrm{P}_{\mathrm{a}}$ are the initial pressure wave amplitude and pressure wave amplitude at a distance $x$ in $a$ cross section with length $d$ and attenuation coefficient, $a$ (alpha). The natural logarithm of Eq. (3) is:

$$
\alpha x=\ln \frac{P_{a}}{P_{0}}
$$

articulated as the attenuation at a distance $x$, a dimensionless number expressed in Nepers $(\mathrm{Np})$. Attenuation coefficient is in $\mathrm{Np} / \mathrm{cm}$ or $\mathrm{dB} / \mathrm{m}$. Since $\log x=\ln x / \ln 10=0.434 \ln x$ and $1 \mathrm{~Np}=8686.0 \mathrm{~dB}$, Eq. (4) can be written as:

$$
\alpha x=20 \log \frac{P_{a}}{P_{0}} \mathrm{~dB}
$$

The relative amplitude, $\beta$, is expressed as:

$$
\beta=20 \log \frac{A_{p}}{A_{p s}} \quad \mathrm{~dB}
$$

where $\beta$ is the measurement of attenuation with $A_{p}$ taken as the first peak amplitude after the arrival of pressure wave (at $t_{p}=$ transit time of UPV through the concrete specimen) and $A_{p s}$ as the peak amplitude after the arrival of shear wave (at $t_{s}=$ two times the transit time of UPV). The location where $t_{s}$ is located is based on the fact that shear wave is slower (about two times) than the pressure wave in concrete. Figure 4 shows the typical oscilloscope display defining the transit time and wave amplitude that delineate the relative amplitude $(\beta)$. As $\beta$ is also a ratio between two amplitudes, it is also known as relative amplitude ratio (RAR).

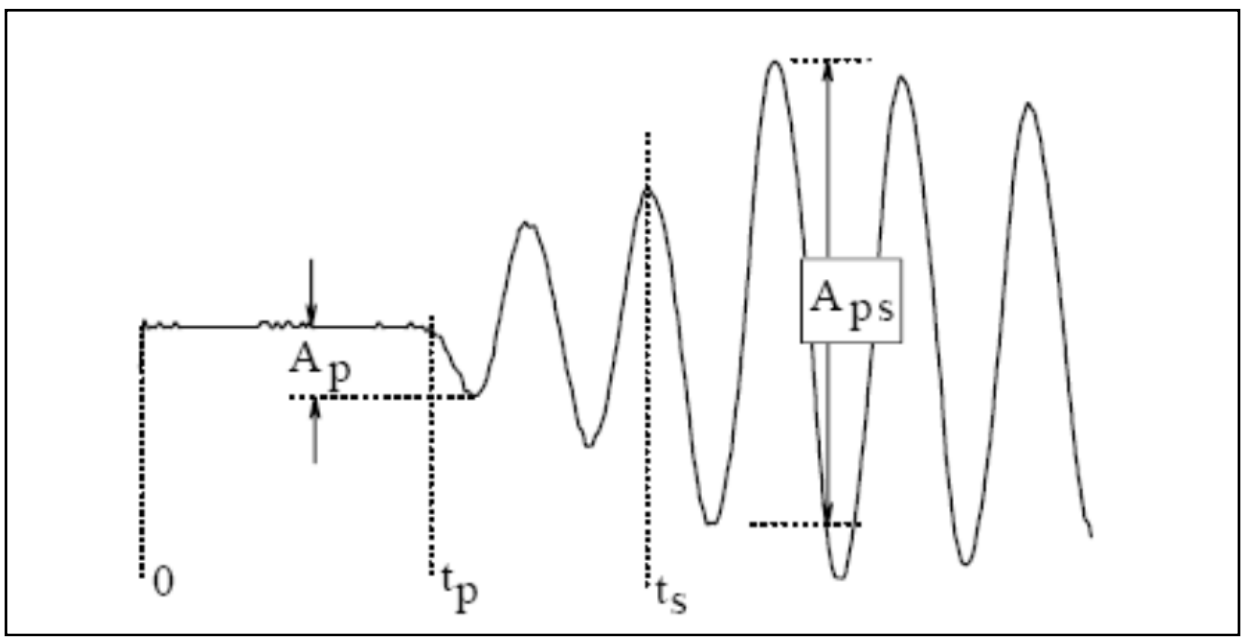

Fig. 4. Typical oscilloscope display defining the transit time and wave amplitude (IAEA TCS17, 2002)

However, consistent and constant coupling pressure for the transducers has to be maintained and will affect the attenuation values. It is suggested that a simple pressure measurement mechanism based on load cell and dial is built to check this problem, though, results discussed here did not include this mechanism. 


\subsection{Results and discussion}

\subsubsection{Ultrasonic pulse velocity-strength relationship of HPC with mineral admixtures}

At high strength, the well established exponential relationship between strength and UPV (Eq. 1) is not sensitive to estimate the strength accurately (UPV between 4.5 to $5 \mathrm{~km} / \mathrm{s}$ for strength range 50 to $100 \mathrm{MPa}$ ). The correlation between strength and UPV is also poor. Uysal \& Yilmaz, 2011 reported the UPV values ranged from $4222 \mathrm{~m} / \mathrm{s}$ to $4998 \mathrm{~m} / \mathrm{s}$ for strength value of 55 to $105 \mathrm{MPa}$ for concrete containing limestone powder (LP), basalt powder (BP) and marble powder (MP). They also found that the use of limestone powder $(\mathrm{LP})$, basalt powder (BP) and marble powder (MP) as cement replacement at various contents had caused a reduction in UPV as well as the compressive strength compared to the control mixture. Increasing amounts of these kind of mineral admixtures (limestone powder, basalt powder and marble powder) generally decrease the strength. The correlation between the compressive strength and UPV is poor $\left(\mathrm{R}^{2}=0.75\right)$ at high strength compare to concrete with mineral admixtures (fly ash, natural zeolite and blast furnace slag) at low strength (Demirbogă et al., 2004; Türkmen et al., 2010).

Khatib, 2008 reported that concrete with $40 \%$ fly ash (FA) mix shows the largest value of UPV compared with the $20 \%$ FA mix. Generally there is a decrease in strength with the increase in FA content. The strength versus UPV values shows an exponential relationship with an $\mathrm{R}^{2}$ of 0.97 but the strength range covered is from $5 \mathrm{MPa}$ up to $85 \mathrm{MPa}$. Khatib, 2008 result also shows that for strength range 50 to $85 \mathrm{MPa}$, the UPV only varies 4.5 to $4.7 \mathrm{~km} / \mathrm{s}$; however the relationship seems to be independent of the FA content.

Silica fume is a mineral admixture that provides early strength gain and high strength gain to HPC. Hamid et al., 2010 reported that at a given strength, specimens with higher content of silica fume (30\%) shows lower readings of UPV compared to specimens with lower content of silica fume (10\% and $20 \%$ ) (Fig. 5). The argument was that the mixture with lower content of silica fume is denser than the mixture with higher content of silica fume at the same water/binder ratio, even though they bear the same strength. The strength-UPV relationship is also reported as exponential form which resulted in at strength higher than $85 \mathrm{MPa}$, the variation of UPV reading reduced. The coefficient of correlation, $\mathrm{R}^{2}$, for strength-UPV curve for HPC with 10\%, 20\% and 30\% silica fume are good which are 0.93 , 0.92 and 0.96 respectively. Hamid et al, 2010 also reported that the sensitivity of the UPV measurement decreased with the increased on HPC with silica fume strength.

For HPC with FA at strength range 50 to $90 \mathrm{MPa}$, Hamid, 2004 found that the correlation between strength and UPV of FAHPC (strength range $50-90 \mathrm{MPa}$ ) is poor (Figure 6). Results of experiments show that using different transducer's frequency gave the same bestfitted line of strength-UPV curve, but the correlation of coefficient using transducer $150 \mathrm{kHz}$ is higher than using transducer $54 \mathrm{kHz}$. Measuring the UPV on saturated samples increase the value of UPV compared to measuring on dry samples. The correlations of the best-fitted line strength-UPV curve for the saturated samples are higher than the correlations of those on dry samples. The compressive strength of mixes with higher content of fly ash decrease compare to mixes with low content of FA. The increase packing density influences the measured UPV very significantly but in reverse to the effect towards strength. Higher content of FA produce higher measured UPV at the same strength level of HPC with lower fly ash content. 


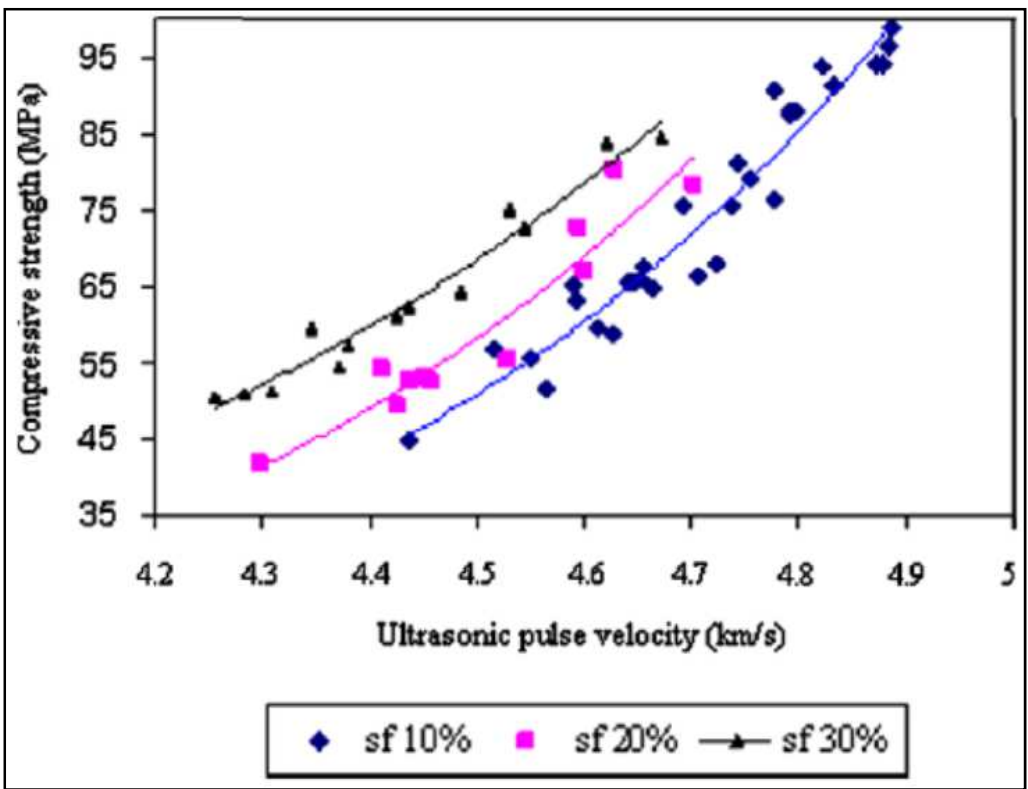

Fig. 5. Relationship between silica fume content with UPV (Hamid et al., 2010)

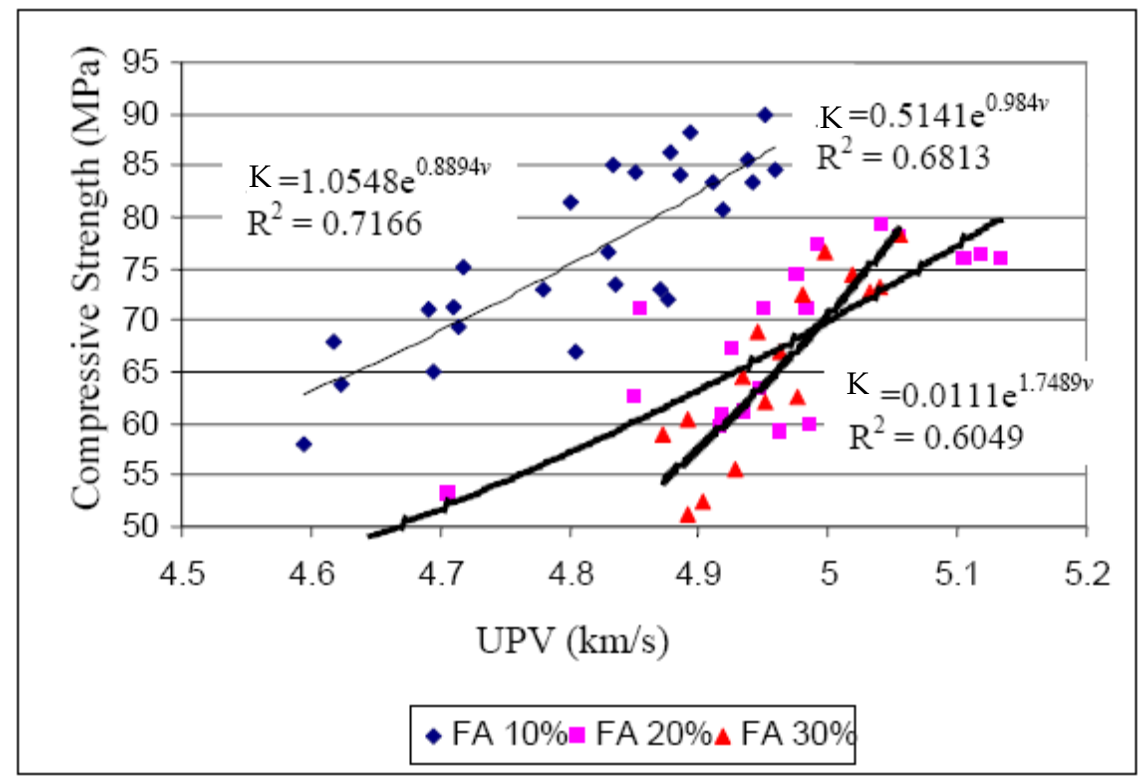

Fig. 6. Relationship between UPV and strength of HPC with fly ash (Hamid, 2004).

It can be concluded that, these phenomena are observed in the measurement of UPV and their relationship with strength of HPC with mineral admixtures: 
1. Ultrasonic pulse velocity (UPV) is not sensitive to estimate the strength accurately (UPV between around 4.2 to $5.0 \mathrm{~km} / \mathrm{s}$ for strength range 50 to $100 \mathrm{MPa}$ ).

2. The correlation of coefficient $\left(R^{2}\right)$ of the UPV-strength curve is poor (below 0.8 ) for all mineral admixtures except silica fume.

3. The content of mineral admixtures in the HPC affects the measured UPV such that at different mineral admixtures content, but at the same strength level, the UPV measured are different. Generally, the UPV is higher in HPC with higher content of mineral admixtures.

\subsubsection{Relative amplitude-strength relationship in HPC with mineral admixtures}

Relative amplitude (RA) method is described in IAEA TCS17, 2002 and general relationship between strength, $K$ and relative amplitude, $\beta$ is an exponential form:

$$
K=e^{c-d \beta}
$$

where $c$ and $d$ are empirical constants.

The relative amplitude decreases as the strength increased. The factors which influence the relationship are the moisture content of concrete; concrete age; aggregate size and type; curing method; bar size and beam path length.

The RA, in contrast with the UPV, shows greater sensitivity towards the strength change, that is, $6-20 \mathrm{~dB}$ for strength range between $5 \mathrm{MPa}$ to $60 \mathrm{MPa}$ of normal concrete with coefficients of correlation greater than $80 \%$ (Ismail, 1996).

Fig. 7 shows that for HPC with silica fume at strength higher than $85 \mathrm{MPa}$, the variation of RA value is $14 \%$ for variation of strength of $40 \mathrm{MPa}$ to $100 \mathrm{MPa}$. The coefficients of correlation, $\mathrm{R}^{2}$, for strength-RA curve for all three series of mixes are $0.54,0.80$ and 0.48 respectively (Hamid et al., 2010).

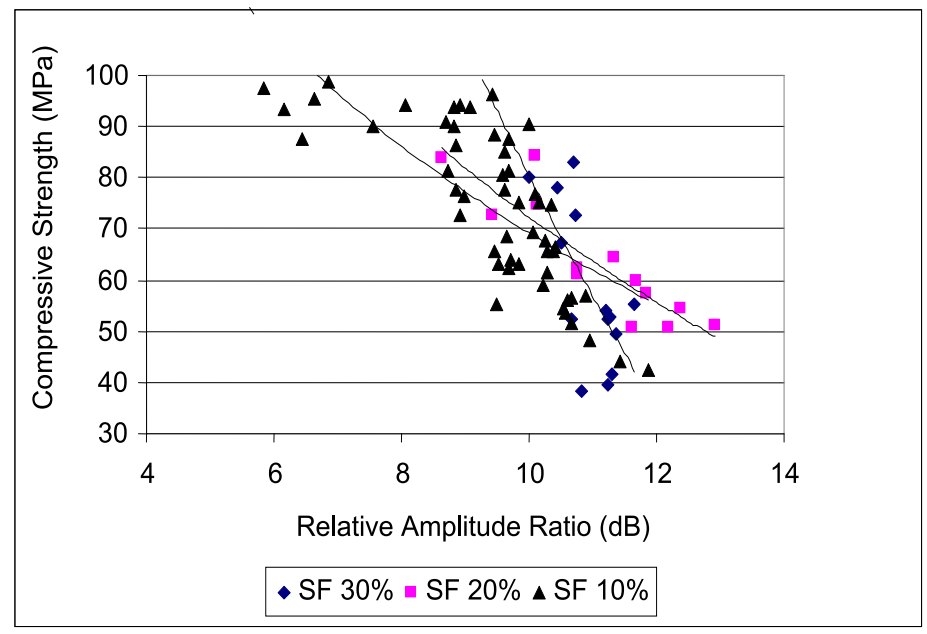

Fig. 7. The relationship between the silica fume content with the relative amplitude (Hamid et al., 2010) 
Figure 8 shows that each series of HPC with different fly ash content exhibits an exponential relationship with the relative amplitude ratio (RAR), which is in the form:

$$
K=c e^{d \beta}
$$

where $K$ is the compressive strength, $\beta$ is the RAR and $c$ and $d$ are the empirical constant.

The RAR, in contrast with the UPV, shows greater sensitivity towards the strength change, that is, $80 \%(2-10 \mathrm{~dB})$ for the same strength rage. The coefficients of correlation are greater than $80 \%$ as shown in Figure 8.

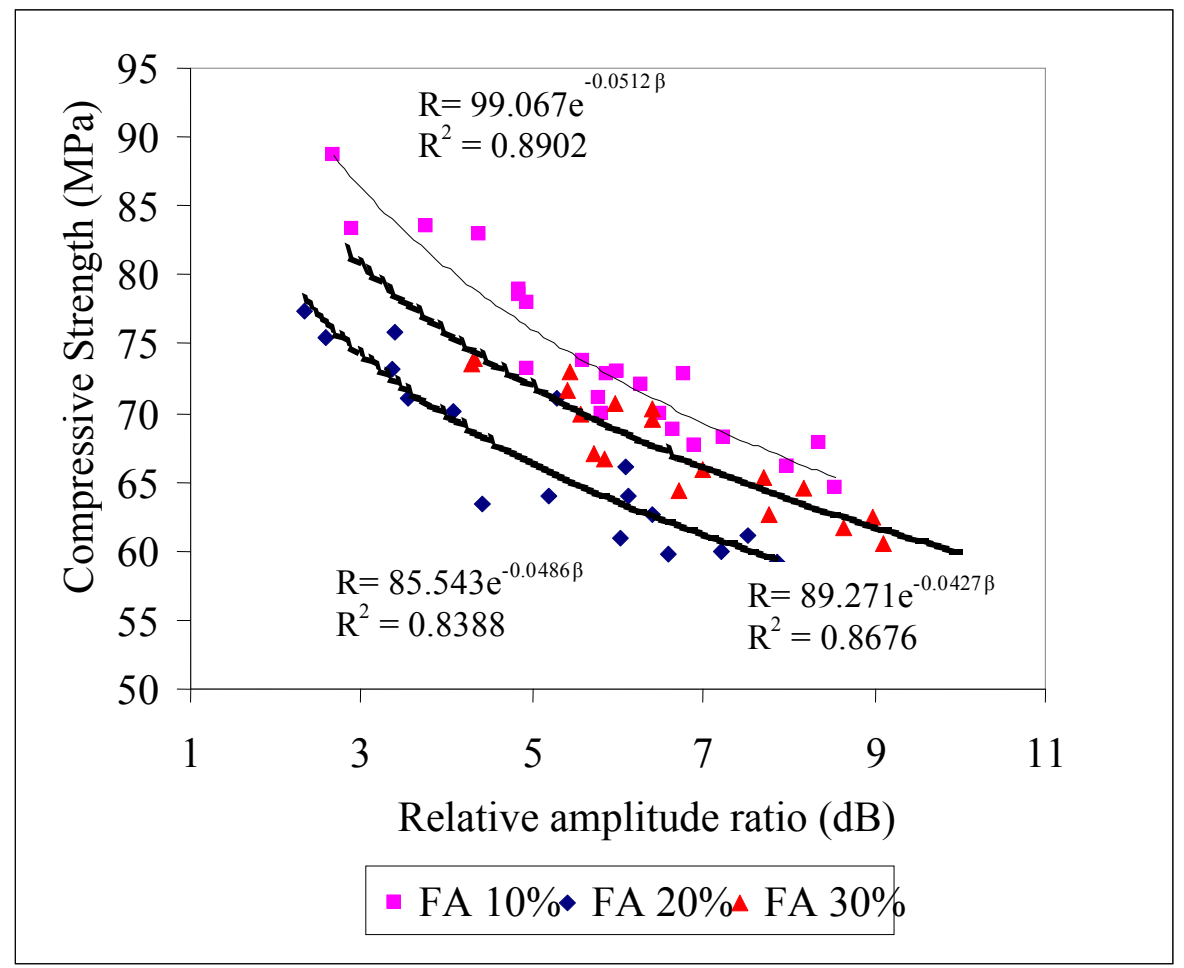

Fig. 8. The relationship between the strength of HPC with FA and the RAR (Hamid , 2004)

\subsection{Factors affecting the UPV-strength relationship of HPC with fly ash}

Tests were done to determine the effect of the transducer's frequency, moisture content, samples' shape, transmission type and FA content on the UPV-strength and RA-strength relationships. The frequencies of the transducers selected for the test are $54 \mathrm{kHz}$ and 150 $\mathrm{kHz}$. Table 2 shows the effect of different transducer's frequency on the correlation coefficient $\left(\mathrm{R}^{2}\right)$ of UPV-strength relationship of HPC with FA. It can be seen from Table 2 that higher transducer frequency gives better correlation coefficient $\left(R^{2}\right)$ of UPV-strength relationship of HPC with FA. 


\begin{tabular}{|c|c|c|c|c|c|c|}
\hline \multirow{2}{*}{$\begin{array}{c}\text { Fly ash } \\
\text { content }\end{array}$} & \multirow{2}{*}{$\begin{array}{c}\mathrm{R}^{2}(54 \mathrm{kHz} \\
\text { transducer })\end{array}$} & \multirow{2}{*}{$\begin{array}{c}\mathrm{R}^{2}(150 \mathrm{kHz} \\
\text { transducer })\end{array}$} & \multicolumn{2}{|c|}{$\begin{array}{c}\text { Empirical } \\
\text { constant (Eq.1) }\end{array}$} & \multicolumn{2}{|c|}{$\begin{array}{c}\text { Empirical } \\
\text { constant (Eq.1) }\end{array}$} \\
\cline { 4 - 7 } & & & $a$ & $b$ & $a$ & $b$ \\
\hline $10 \%$ & 0.8921 & 0.7075 & 2.8076 & 0.6873 & 0.8252 & 0.9507 \\
\hline $20 \%$ & 0.4466 & 0.5317 & 9.2439 & 0.4142 & 9.0802 & 0.4195 \\
\hline $30 \%$ & 0.0007 & 0.4205 & 108.42 & -0.0945 & 0.0034 & 1.9929 \\
\hline
\end{tabular}

Table 2. Effect of transducer's frequency on the correlation coefficient $\left(\mathrm{R}^{2}\right)$ of UPV-strength relationship of HPC with FA

The samples were then submerged in water for more than 72 hours and tested. The increases in moisture content recorded are between $0.4 \%$ and $0.8 \%$. Table 3 shows the effect of moisture content on the correlation coefficient $\left(\mathrm{R}^{2}\right)$ of UPV-strength relationship of HPC with FA. Saturated samples give better correlation coefficient $\left(R^{2}\right)$ of UPV-strength relationship of HPC with FA.

\begin{tabular}{|c|c|c|c|}
\hline $\begin{array}{c}\text { Fly ash } \\
\text { content }\end{array}$ & $\begin{array}{c}\mathrm{R}^{2}(54 \mathrm{kHz}, \\
\text { saturated) }\end{array}$ & $\begin{array}{c}\mathrm{R}^{2}(150 \mathrm{kHz}, \\
\text { saturated })\end{array}$ & $\begin{array}{c}\mathrm{R}^{2}(150 \mathrm{kHz}, \\
\text { air dry })\end{array}$ \\
\hline $10 \%$ & 0.6253 & 0.8023 & 0.7075 \\
\hline $20 \%$ & 0.5521 & 0.6808 & 0.5317 \\
\hline $30 \%$ & 0.4503 & 0.4387 & 0.4205 \\
\hline
\end{tabular}

Table 3. Effect of moisture content on the correlation coefficient $\left(\mathrm{R}^{2}\right)$ of UPV-strength relationship of HPC with FA

Cylindrical samples of $200 \mathrm{~mm}$ in height and $100 \mathrm{~mm}$ in diameter with the same mix proportions were tested and the resulting UPV measured are compared with those of 150 $\mathrm{mm}^{3}$ cube samples. Results show that UPV measured in cubes are higher than in cylinders at the same strength level. Equation 9 shows the relationship between the UPV measured in cubes and cylinders:

$$
v_{\text {cylinder }}=0.6115 v_{\text {cube }}+1.7953
$$

for $v_{\text {cube }}>4.6 \mathrm{~km} / \mathrm{s}$.

As described in IAEA TCS17, 2002, the ultrasonic pulse transmission types affect the value of the measured UPV. The transmission types are the direct, semi direct and indirect transmission. Equations 10 and 11 show the relationship between the UPV measured using indirect method, semi direct method and the direct method:

$$
\begin{aligned}
& v_{\text {direct }}=1.2089 v_{\text {semi direct }} \\
& v_{\text {direct }}=1.3000 v_{\text {indirect }}
\end{aligned}
$$

It is observed than there is an increase in the indirect (surface) transmission correction factor (CF) for HPC with fly ash compared to 1.05 reported for normal concrete in BS 1881: Part 203. 


\subsection{Correction factors concerning UPV-strength and RA-strength relationships of HPC with fly ash}

Tests were also done to determine the effect of the transducer's frequency, moisture content, samples' shape, transmission type and FA content on the RA-strength. Table 4 shows the correction factor $(\mathrm{CF})$ suggested from the analysis the test results.

\begin{tabular}{|c|c|c|}
\hline \multirow[b]{2}{*}{$\begin{array}{l}\text { Fly ash } \\
\text { content }\end{array}$} & \multicolumn{2}{|c|}{ Correction Factor (CF) } \\
\hline & $\begin{array}{c}\mathrm{UPV} \\
\mathrm{V} 150 \mathrm{kHz}=\mathrm{CFV} 54 \\
\mathrm{kHz}\end{array}$ & $\begin{array}{c}\text { RA } \\
\beta_{150 \mathrm{kHz}}=\mathrm{CF} \beta_{54 \mathrm{kHz}}\end{array}$ \\
\hline $10 \%$ & 1.0041 & 1.6397 \\
\hline $20 \%$ & 0.9969 & 1.5463 \\
\hline $30 \%$ & 1.0211 & 1.5417 \\
\hline
\end{tabular}

Table 4. Correction factors applied with different transducer's frequency for UPV and RAstrength relationship of HPC with FA

On the other hand, effect of moisture content on UP-strength and RA-strength curve are found to be insignificant as shown in Equations 12 and 13:

$$
\begin{aligned}
& v_{\text {saturated }}=1.0034 v_{\text {dry }} \\
& \beta_{\text {saturated }}=1.0021 \beta_{\text {dry }}
\end{aligned}
$$

The effect of fly ash content on the UPV and RA-strength correlation curves for HPC with fly ash compared to the same mix design without fly ash content (FA $0 \%)$ is as shown in Table 5.

\begin{tabular}{|c|c|c|}
\hline \multirow{2}{*}{$\begin{array}{c}\text { Fly ash } \\
\text { content }\end{array}$} & \multicolumn{2}{|c|}{ Correction Factor $(\mathrm{CF})$} \\
\cline { 2 - 3 } & $\mathrm{UPV}$ & RA \\
\hline $10 \%$ & $v_{\mathrm{FA} 10 \%}=1.4942 v_{\mathrm{FA} 0}-2.521$ & $\beta_{\mathrm{FA} 10 \%}=0.2711 \beta_{\mathrm{FA} 0} \%{ }^{1.8769}$ \\
\hline $20 \%$ & $v_{\mathrm{FA} 20 \%}=1.3250 v_{\mathrm{FA} 0} \%-1.4169$ & $\beta_{\mathrm{FA} 20 \%}=0.0594 \beta_{\mathrm{FA} 0}{ }^{2.4494}$ \\
\hline $30 \%$ & $v_{\mathrm{FA} 30 \%}=0.6587 v_{\mathrm{FA} 0} \%-1.8073$ & $\beta_{\mathrm{FA} 30 \%}=0.1199 \beta_{\mathrm{FA} 0 \%}{ }^{2.2340}$ \\
\hline
\end{tabular}

Table 5. Correction Factor (CF) applied with different fly ash content for UPV and RAstrength relationship of HPC with FA

\section{Conclusion}

This chapter emphasizes on ultrasonic pulse velocity (UPV) and relative amplitude (RA) method in assessing the strength of high performance concrete (HPC) with mineral admixtures such as fly ash. Adding mineral admixtures to replace certain percentages of cement content increase or decrease the strength of HPC compare to the same concrete combination containing only ordinary Portland cement (OPC). By using extremely fine pozzolanic material, such as fly ash, the compactness of the concrete improves because the fly ash fills the micro voids in grain packing. This feature results in higher measured UPV values in higher fly ash content concrete compared to lower fly ash content concrete at the same measured compressive strength. The strength-UPV correlation in HPC with fly ash is found to be poor (correlation coefficient, $\mathrm{R}^{2}$, reduces with increase of fly ash content). HPC 
with silica fume samples produces good strength-UPV correlation but, as with the case of fly ash concrete, the silica fume content affects the measured UPV significantly. The correction factor for fly ash content is proposed. It is recommended that when establishing iso-strength curve for concrete with mineral admixtures, correction factor for each mineral admixture is included.

\section{References}

Carino, N.J. (1994). Nondestructive Testing of Concrete: History and Challenges, In: Concrete Technology - Past, Present and Future, Mehta, P.K., (Ed.), 623-678, ACI SP144, American Concrete Institute, Detroit, MI.

Demirbogă, R., Türkmen, İ. and Karakoc, M. B. (2004). Relationship between ultrasonic velocity and compressive strength for high-volume mineral-admixtured concrete. Cement and Concrete Research, Vol. 34, pp.2329-2336.

Galan, A. (1990). Combined Ultrasound Methods of Concrete Testing. Elsevier, Amsterdam, North Holland.

Hamid, R. (2004). The Characteristics of Ultrasonic Wave in Hardened High Performance Concrete with Fly Ash and Silica Fume (in Malay), PhD Thesis, Universiti Kebangsaan Malaysia, Malaysia.

Hamid, R., Yusof, K.M., Zain and M.F.M. (2010). A combined ultrasound method applied to high performance concrete with silica fume, Construction and Building Materials, Vol. 24, No, 1, (January 2010), pp. 94-98, ISSN 0950-0618.

International Atomic Energy Agency TCS 17, Guidebook on Non-Destructive Testing of Concrete Structures, Vienna, 2002.

Ismail, M.P., Yusof, K.M. and Ibrahim, A.N. (1996). A combined ultrasonic method on the estimation of compressive concrete strength. INSIGHT, Vol. 38, No. 11, (November 1996), pp. 781-785.

Khatib, J.M. 2008. Performance of self-compacting concrete containing fly ash. Construction and Building Materials, Vol. 22, No. 9, pp.1963-1971. ISSN 0950-0618.

Krautkramer, J. and Krautkramer, H. (1983). Ultrasonic Testing of Materials. (3rd ed.). Springer-Verlag, Berlin.

Malier, Y. (1992). Introduction, In: High Performance Concrete: From Material to Structure, Yves Malier, pp. (xiii - xxiv), E \& F Spon, ISBN 0419176004, London, UK.

PCA EB001, Design and Control of Concrete Mixtures, 14th edition, Portland Cement Association. 2002.

Price, W.F. and Hynes, J.P. 1996. In-situ testing of high strength concrete. Magazine of Concrete Research. Vol. 48, No.176, pp. 189-197.

Shah, S.P. 1997. High performance concrete: controlled performance concrete. Magazine of Concrete Research. Vol. 49, No: 178, pp. 1-3.

Türkmen, I., Öz, A. and Aydin, A. C. (2010). Characteristics of workability, strength, and ultrasonic pulse velocity of SCC containing zeolite and slag. Scientific Research and Essays, Vol. 5, No.15, pp. 2055-2064.

Uysal, M. and Yilmaz, K. (2011). Effect of mineral admixtures on properties of selfcompacting concrete. Cement \& Concrete Composites, Vol. 33, pp. 771-776, ISSN 09589465. 
NONDESTRUCTIVE

TESTING METHODS

AND NEW

APPLICATIONS

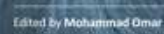

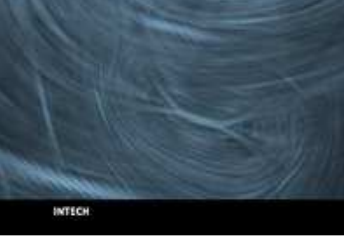

\section{Nondestructive Testing Methods and New Applications}

Edited by Dr. Mohammad Omar

ISBN 978-953-51-0108-6

Hard cover, 264 pages

Publisher InTech

Published online 02, March, 2012

Published in print edition March, 2012

Nondestructive testing enables scientists and engineers to evaluate the integrity of their structures and the properties of their materials or components non-intrusively, and in some instances in real-time fashion. Applying the Nondestructive techniques and modalities offers valuable savings and guarantees the quality of engineered systems and products. This technology can be employed through different modalities that include contact methods such as ultrasonic, eddy current, magnetic particles, and liquid penetrant, in addition to contact-less methods such as in thermography, radiography, and shearography. This book seeks to introduce some of the Nondestructive testing methods from its theoretical fundamentals to its specific applications.

Additionally, the text contains several novel implementations of such techniques in different fields, including the assessment of civil structures (concrete) to its application in medicine.

\section{How to reference}

In order to correctly reference this scholarly work, feel free to copy and paste the following:

R. Hamid, K. M. Yusof and M. F. M. Zain (2012). Ultrasonic Testing of HPC with Mineral Admixtures, Nondestructive Testing Methods and New Applications, Dr. Mohammad Omar (Ed.), ISBN: 978-953-51-01086, InTech, Available from: http://www.intechopen.com/books/nondestructive-testing-methods-and-newapplications/ultrasonic-testing-of-hpc-with-mineral-admixtures

\section{INTECH}

open science | open minds

\author{
InTech Europe \\ University Campus STeP Ri \\ Slavka Krautzeka 83/A \\ 51000 Rijeka, Croatia \\ Phone: +385 (51) 770447 \\ Fax: +385 (51) 686166 \\ www.intechopen.com
}

\author{
InTech China \\ Unit 405, Office Block, Hotel Equatorial Shanghai \\ No.65, Yan An Road (West), Shanghai, 200040, China \\ 中国上海市延安西路65号上海国际贵都大饭店办公楼 405 单元 \\ Phone: +86-21-62489820 \\ Fax: +86-21-62489821
}


(C) 2012 The Author(s). Licensee IntechOpen. This is an open access article distributed under the terms of the Creative Commons Attribution 3.0 License, which permits unrestricted use, distribution, and reproduction in any medium, provided the original work is properly cited. 